Vol. 1 No. 2 September 2021 e-ISSN : 2797-3344 P-ISSN : 2797-3336

\title{
UPAYA MENINGKATKAN HASIL BELAJAR MATEMATIKA MENGGUNAKAN STRATEGI PROBLEM BASED LEARNING SISWA KELAS 1 SDN 3 SAKRA SELATAN KECAMATAN SAKRA SEMESTER II TAHUN PELAJARAN 2020/2021
}

\author{
MASITAH \\ SD Negeri 3 Sakra Selatan Kabupaten Lombok Timur \\ Masitah011@gmail.com
}

\begin{abstract}
ABSTRAK
Strategi pembelajaran ini juga cocok dengan tujuan pembelajaran karena tujuan pembelajaran matematika pada kelas 1 semester II salah satunya adalah peserta didik mampu menyelesaikan masalah kehidupan sehari-hari berkaitan dengan penjumlahan dan pengurangan bilangan yang melibatkan bilangan cacah sampai dengan 99. Tujuan dalam penelitian ini adalah untuk meningkatkan hasil belajar matematika dengan menggunakan strategi problem based learning siswa kelas 1 SDN 3 Sakra Selatan tahun pelajaran 2020/2021. Metode yang digunakan adalah metode Penelitian Tindakan Kelas (PTK). Dalam penelitian tindakan kelas (PTK) ini dilakukan dalam 2 siklus, dari hasil tindakan yang dilakukan terbukti dapat meningkatkan ketuntasan belajar siswa secara klasikal yaitu pada siklus I sebesar 69\%, dapat meningkat menjadi $100 \%$ pada siklus II. Hasil penelitian tindakan kelas ini menunjukkan bahwa pembelajaran dengan meningkatkan hasil belajar matematika menggunakan strategi Problem Based Learning mencapai ketuntasan mencapai 95\%.
\end{abstract}

Kata Kunci: Hasil Belajar, Problem Based Learning

\section{ABSTRACT}

This learning strategy is also suitable for learning objectives because the objectives of learning mathematics in class 1 semester II are for students to be able to solve problems of daily life related to addition and subtraction of numbers involving whole numbers up to 99 . The purpose of this study was to improve learning outcomes of mathematics using a problem based learning strategy for grade 1 students of SDN 3 Sakra Selatan for the 2020/2021 academic year. The method used is Classroom Action Research (CAR). In this class action research (CAR) was carried out in 2 cycles, from the results of the actions taken it was proven to be able to increase student learning mastery classically, namely in the first cycle by $69 \%$, it could increase to $100 \%$ in the second cycle. The results of this classroom action research indicate that learning by improving mathematics learning outcomes using Problem Based Learning strategies reaches $95 \%$ of completeness.

Keywords: Learning Outcomes, Problem Based Learning

\section{PENDAHULUAN}

Proses pendidikan tidak pernah terlepas dari kegiatan belajar dan pembelajaran di dalam kelas. Pembelajaran merupakan aktifitas interaksi edukatif antara pembelajar dengan peserta didik dengan didasari oleh adanya tujuan baik berupa pengetahuan, sikap, maupun keterampilan. Pengertian lain tentang pembelajaran, menurut Gagne \& Brigss adalah proses yang diselenggarakan oleh pendidik untuk membelajarkan peserta didik dalam belajar, bagaimana memperoleh dan memproses pengetahuan, keterampilan, dan sikap (Ningrum, 2012:48). Perubahan yang ada pada seluruh aspek kehidupan menuntut aspek pendidikan untuk berubah dan berkembang pula. Tak cukup sampai disitu, perubahan ini harus didukung oleh sumber daya manusia, sistem, dan fasilitas yang memadai. Dalam hal ini, tentu bukan hanya peran pemerintah yang diperlukan, namun juga upaya dan dukungan dari kalangan pendidik, peserta didik, serta wali peserta didik. Pendidik harus menggunakan berbagai strategi dan strategi untuk meningkatkan proses pembelajaran agar efektif. Selain itu, dari sisi peserta didik sendiri harus aktif dalam pembelajaran, termasuk dukungan dari orang tua untuk membuat anaknya termotivasi dalam belajar. Penggunaan metode dan strategi pembelajaran yang sesuai, 
dengan keaktifan peserta didik tentu akan membuat suasana belajar dan hasil belajar menjadi maksimal.

Namun, masalah yang ditemui di SDN 3 Sakra Selatan adalah sebagian siswa kurang memahami bagaimana cara menghitung penjumlahan dan pengurangan terutama dalam nilai belasan dan puluhan. Menurut wawancara dengan guru kelas, kebanyakan siswa kurang mampu dalam menentukan nilai tempat dan nilai angka sehingga dalam melakukan operasi penjumlahan dan pengurangan siswa masih sulit menentukan jawaban. Siswa juga kurang mampu menghitung karena kurangnya pemahaman ketika dihadapkan dengan soal, mereka belum mampu memahami soal sehingga membuat jawaban mereka salah, dan ini berkaitan dengan kemampuan membaca dan berhitung di kelas 1 .

Oleh karena itu, mencoba berbagai model, strategi, serta metode pembelajaran merupakan salah satu cara untuk membuat pembelajaran menjadi aktif, efektif, dan mencapai tujuan pembelajaran. Salah satu dari strategi pembelajaran ini adalah problem based learning. Penerapan strategi problem based learning dalam pembelajaran dapat mengaktifkan siswa dalam proses pembelajaran, dimana siswa terlibat secara langsung dalam proses penemuan pemahaman materi yang diajarkan, sehingga siswa dapat lebih memahami materi yang diajarkan guru. Pembelajaran matematika pada kelas 1 bukan termasuk hal yang mudah untuk dilakukan. Diperlukan kemampuan menjelaskan dari guru, bahan ajar yang sesuai, strategi yang tepat, serta worksheet yang menarik untuk peserta didik. Karena dalam sebuah kelas juga ada banyak karakter peserta didik, maka hal-hal seperti cara komunikasi di kelas juga perlu diperhatikan. Tak hanya itu, gurupun seharusnya bekerja sama dengan orang tua peserta didik agar menambah motivasi belajar dan meningkatkan keefektifan belajar.

Christina (2014:18) Problem based learning pertama kali dilakukan di jurusan kesehatan diUniversitas McMaster dimana yang memprakarsai adalah Barrows. Setelah Barrows sukses di jurusan kesehatan, problem based learning mulai digunakan untuk jurusan lain, seperti hukum, perawat, dan bisnis. Menurut Arends (dalam Fachrurazi, 2011:18) problem based learning merupakan suatu pendekatan dimana siswamengerjakan permasalahan yang autentik dengan maksud untuk menyusun pengetahuan mereka sendiri, mengembangkan inkuiri dan keterampilan berpikir, mengembangkan kepribadian, dan percaya diri. Hal senada diungkapkan pula oleh Suryadi yang menyatakan bahwa problem based learning merupakan suatu strategi yang dimulai denganmenghadapkan siswa pada masalah nyata atau masalah yang disimulasikan. Pada saat siswa menghadapi masalah tersebut, mereka mulai menyadari bahwa hal demikian dapat dipandang dari berbagai perspektif serta menyelesaikannya dibutuhkan pengintegrasian informasi dari berbagai ilmu. Menurut Slavin karakteristik lain dari problem based learning meliputi pengajuan pertanyaan terhadap masalah, fokus pada keterkaitan antar disiplin, penyelidikan authentik, kerja sama, dan menghasilkan produk atau karya yang harus dipamerkan.

Sejalan dengan pendapat yang dikemukakan oleh Slavin, menurut Pierce dan Jones dalam pelaksanaan problem based learning terdapat proses yang harus dimunculkan, seperti: keterlibatan (engagement), inkuiri dan investigasi (inquiry and investigation), kinerja (performance), tanya jawab dan diskusi (debriefing). Keterlibatan bertujuan untuk mempersiapkan siswa untuk berperan sebagai pemecah masalah (self-directed problem solver) yang bisa bekerja sama dengan pihak lain, menghadapkan siswa pada situasi yang mampu mendorong untuk mampu menemukan masalah, meneliti dan menyelesaikannya. Inkuiri dan investigasi yang meliputi kegiatan mengeksplorasi berbagai cara menjelaskan dan implikasinya, serta kegiatan mengumpulkan dan mendistribusikan informasi. Kinerja bertujuan menyajikan temuan yang diperoleh. Tanya jawab dan diskusi, yaitu menguji keakuratan dari solusi dan melakukan refleksi terhadap pemecahan masalah yang dilakukan.

Peran guru dalam problem based learning berbeda dengan peran guru dalam kelas. Guru dalam problem based learning harus berpikir tentang beberapa hal, yaitu bagaimana dapat merancang dan menggunakan permasalahan yang ada di dunia nyata sehingga siswa dapat menguasai hasil belajar, bagaimana bisa menjadi pelatih siswa dalam proses pemecahan 
masalah, pengarahan diri, dan belajar dengan teman sebaya. Ketiga adalah bagaimana siswa memandang diri mereka sendiri sebagai pemecah masalah yang aktif. Sanjaya (2011:216) hakikat masalah dalam problem based learning adalah kesenjangan antara situasi nyata dan kondisi yang diharapkan, atau antara kenyataan yang terjadi dengan apa yang diharapkan. Oleh karena itu, materi atau topik tidak terikat pada buku mata pelajaran, namun juga bersumber dari peristiwa sehari-hari.

Prasetyo, (2014:92) Strategi pembelajaran berbasis masalah merupakan sebuah strategi pembelajaran yang menggunakan masalah autentik dan kompleks sebagai langkah awal untuk mengajarkan berpikir tingkat tinggi serta kemampuan investigasi bagi peserta didik dengan metode ilmiah. Dipilihnya strategi pembelajaran ini adalah karena sesuai dengan karakteristik siswa yang aktif. Kelas 1 di SDN 3 Sakra Selatan masih senang bermain dan mereka dapat melaksanakan tugas kelompok dengan bimbingan guru. Strategi problem based learning juga cocok dengan karakteristik mata pelajaran matematika yaitu memiliki objek kajian abstrak, berpola berpikir deduktif, memiliki simbol yang kosong dari arti, memperhatikan semesta pembicaraan, konsisten dalam sistemnya, dan bertumpu pada kesepakatan. Strategi pembelajaran ini juga cocok dengan tujuan pembelajaran karena tujuan pembelajaran matematika pada kelas 1 semester 2 salah satunya adalah peserta didik mampu menyelesaikan masalah kehidupan sehari-hari berkaitan dengan penjumlahan dan pengurangan bilangan yang melibatkan bilangan cacah sampai dengan 99. Sebelumnya, strategi problem based learning ini pernah digunakan Fachrurazi untuk meningkatkan kemampuan berpikir kritis dan komunikasi matematis.

\section{METODE PENELITIAN}

Subyek penelitian adalah siswa kelas I SD Negeri 3 Sakra Selatan kecamatan Pringgasela kabupaten Lombok Timur tahun pelajaran 2020/2021 yang berjumlah 22 siswa dan terdiri atas 12 siswa laki-laki dan 10 siswa perempuan dengan usia rata-rata 6-7 tahun. Karena covid-19 maka subyek penelitian diambil 11 siswa. Penelitian ini dilaksanakan di kelas I SD Negeri 3 Sakra Selatan kecamatan Pringgasela kabupaten Lombok Timur yang merupakan tempat tugas peneliti.

Penelitian ini dilaksanakan dengan menggunakan dua siklus, dengan setiap siklusnya dilaksanakan 2 kali pertemuan. Penelitian ini dilaksanakan selama kurang lebih tiga bulan, yaitu mulai Bulan Januari sampai dengan Maret 2021.

Adapun prosedur penelitian untuk masing-masing tahap adalah sebagai berikut:

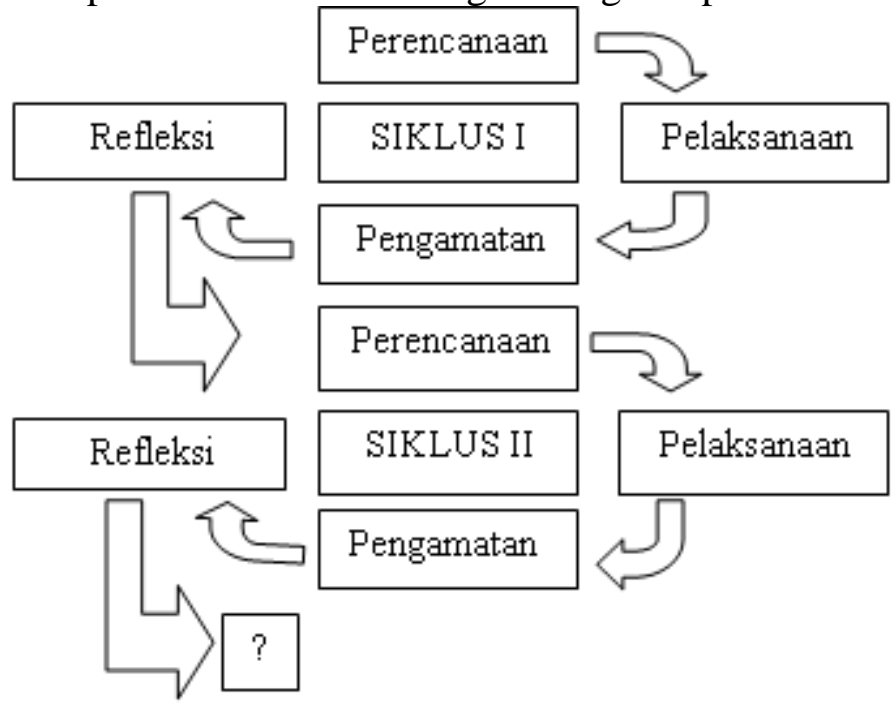

(Suharsimi Arikunto,2008: 16)

Tiap siklus terdiri dari perencanaan, pelaksanaan, pengamatan, dan refleksi. Instrumen pembelajaran yang digunakan dalam penelitian ini ada dua yaitu instrumen pelaksanaan pembelajaran yang digunakan berupa silabus dan rencana pelaksanaan pembelajaran (RPP), dan instrument pengumpulan data yang terdiri dari dokumentasi, observasi, dan tes. 
Untuk mengetahui aktivitas dalam pembelajaran, maka data hasil observasi yang berupa skor diolah dengan rumus:

$$
\mathrm{A}=\frac{\sum X}{n . i}
$$

Keterangan :

$$
\begin{array}{ll}
\mathrm{A} & =\text { Skor rata-rata aktivitas belajar siswa } \\
\sum X & =\text { Jumlah skor aktivitas belajar seluruhnya } \\
\mathrm{i} & =\text { Banyaknya item } \\
\mathrm{n} & =\text { banyaknya siswa }
\end{array}
$$

Untuk menilai kategori aktivitas siswa, ditentukan terlebih dahulu $\mathrm{M}_{\mathrm{i}}$ dan $\mathrm{SD}_{\mathrm{i}}$ dengan rumus sebagai berikut:

$$
\begin{array}{r}
M_{i}=\frac{1}{2} \times(\text { Skor max }+ \text { Skor min }) \\
S D_{i}=\frac{1}{3} M_{\mathrm{i}}(\text { Nurkencana, 1990:100) }
\end{array}
$$

Keterangan :

$$
\begin{aligned}
& M_{i}=\text { Mean ideal } \\
& S D_{i}=\text { Standar Deviasi ideal }
\end{aligned}
$$

Tabel 1. Pedoman skor standar aktivitas belajar siswa

\begin{tabular}{|c|c|}
\hline Interval & Kategori \\
\hline$A S \geq M_{i}+1,5 \mathrm{SD}_{\mathrm{i}}$ & Sangat Aktif \\
$\mathrm{M}_{\mathrm{i}}+0,5 \mathrm{SD}_{\mathrm{i}} \leq \mathrm{AS}<\mathrm{M}_{\mathrm{i}}+1,5 \mathrm{SD}_{\mathrm{i}}$ & Aktif \\
$\mathrm{M}_{\mathrm{i}}-0,5 \mathrm{SD}_{\mathrm{i}} \leq \mathrm{AS}<\mathrm{M}_{\mathrm{i}}+0,5 \mathrm{SD}_{\mathrm{i}}$ & Cukup Aktif \\
$\mathrm{M}_{\mathrm{i}}-1,5 \mathrm{SD}_{\mathrm{i}} \leq \mathrm{AS}<\mathrm{M}_{\mathrm{i}}-0,5 \mathrm{SD}_{\mathrm{i}}$ & Kurang Aktif \\
$\mathrm{AS}<\mathrm{M}_{\mathrm{i}}-1,5 \mathrm{SD}_{\mathrm{i}}$ & Sangat Kurang Aktif \\
\hline
\end{tabular}

\section{HASIL DAN PEMBAHASAN \\ Siklus I \\ Perencanaan}

Tahap awal dimulai dengan menyiapkan Rencana Pelaksanaan Pembelajaran (RPP) sesuai dengan Kompetensi Inti pada Kurikulum 2013, menyiapkan soalevaluasi, lembar observasi guru, dan lembar observasi siswa.

\section{Pelaksanaan Tindakan}

Dalam tahap pelaksanaan tindakan dilaksanakan kegiatan pembelajaran sesuai dengan rencana pelaksanaan pembelajaran yang telah dibuat. Untuk dapat menyesuaikan rencana pelaksanaan pembelajaran dalam penyampaian materi, termasuk didalamnya pembelajaran dengan menggunakankemampuan berhitung penjumlahan dan pengurangan pada kurikulum 2013 tema 7 subtema 3 menggunakan strategi problem based learningdilaksanakan dalam 3 kali pertemuan, dimana 2 kali pertemuan untuk penyampaian materi yaitu pada pekan pertama dan 1 kali pertemuan untuk evaluasi yaitu pada pekan kedua bulan Februari 2021

\section{Observasi dan Evaluasi}

Berdasarkan hasil observasi terhadap aktivitas siswa setelah dianalisa diperoleh data sebagai berikut:

Tabel 2. Hasil Observasi Aktivitas Siswa Pada Siklus I

\begin{tabular}{cccccccccc}
\hline Pertemuan & \multicolumn{1}{c}{ Jumlah skor yang tampak } & $\begin{array}{c}\Sigma \\
\text { Skor } \\
\text { aktivitas }\end{array}$ & $\begin{array}{c}\text { Rata-rata } \\
\text { Aktivitas }\end{array}$ & Kategori \\
& 1 & 2 & 3 & 4 & 5 & 6 & & Kurang \\
Pertama & 3,0 & 2,7 & 2,0 & 2,3 & 2,3 & 2,3 & 14,6 & 2,4 & aktif \\
Kedua & 3,3 & 3,0 & 3,0 & 3,3 & 3,3 & 3,0 & 18,9 & 3,2 & Cukup aktif \\
\hline
\end{tabular}


Vol. 1 No. 2 September 2021 e-ISSN : 2797-3344 P-ISSN : 2797-3336

Dari tabel di atas dapat dilihat bahwa aktivitas belajar siswa pada siklus I pertemuan 1 adalah 2,4 dengan kategorikurang aktif dan pertemuan 2 adalah 3,2 kategori cukup aktif. Tingkat aktivitas siswa ini tergolong belum berhasil. Oleh karena itu maka aktivitas siswa pada siklus berikutnya masih perlu ditingkatkan.

Data lengkap tentang prestasi belajar siswa pada siklus 1. setelah dianalisis diperoleh data sebagai berikut:

Tabel 3. Distribusi Nilai Hasil Ulangan Siklus 1

\begin{tabular}{|c|c|c|c|c|}
\hline \multirow{2}{*}{ No } & \multirow{2}{*}{ NAMA SISWA } & \multirow{2}{*}{ Nilai } & \multicolumn{2}{|c|}{ Keterangan } \\
\hline & & & Tuntas & Tidak Tuntas \\
\hline 1 & AHF & 70 & $\sqrt{ }$ & \\
\hline 2 & $\mathrm{AM}$ & 60 & & $\sqrt{ }$ \\
\hline 3 & ANB & 60 & & $\sqrt{ }$ \\
\hline 4 & AYR & 80 & $\sqrt{ }$ & \\
\hline 5 & $\mathrm{AR}$ & 80 & $\sqrt{ }$ & \\
\hline 6 & DA & 70 & $\sqrt{ }$ & \\
\hline 7 & DYP & 60 & & $\sqrt{ }$ \\
\hline 8 & GPM & 70 & $\sqrt{ }$ & \\
\hline 9 & II & 70 & $\sqrt{ }$ & \\
\hline 10 & KA & 70 & $\sqrt{ }$ & \\
\hline 11 & LFM & 70 & $\sqrt{ }$ & \\
\hline \multicolumn{2}{|c|}{ Jumlah } & 760 & & \\
\hline \multicolumn{2}{|c|}{ Nilai rata-rata } & 69 & & \\
\hline \multicolumn{2}{|c|}{ Nilai tertinggi } & 80 & & \\
\hline \multicolumn{2}{|c|}{ Nilai terendah } & 60 & & \\
\hline \multicolumn{2}{|c|}{ Jumlah Siswa Yang Tuntas } & \multicolumn{3}{|c|}{8 Siswa } \\
\hline \multicolumn{2}{|c|}{ Persentase Ketuntasan secara Klasikal } & \multicolumn{3}{|c|}{$73 \%$ ( Belum Tuntas) } \\
\hline
\end{tabular}

Dari tabel di atas dapat dilihat bahwa ketuntasan belajar yang dicapai siswa adalah $73 \%$ dengan nilai rata-rata 69. Hasil ini belum mencapai ketuntasan belajar secara klasikal sehingga pembelajaran dilanjutkan ke siklus berikutnya.

\section{Refleksi}

Berdasarkan analisis hasil observasi pada siklus I, jumlah siswa yang tuntas masih $73 \%$ berarti masih dibawah standar minimum yakni $85 \%$. Hasil tersebut belum mencapai hasil yang diharapkan, untuk itu peneliti melanjutkan ke siklus berikutnya. Dalam siklus I ini terdapat kekurangan-kekurangan yang perlu untuk dipehatikan dan diperbaiki pada kegiatan siklus II

\section{Siklus II}

\section{Perencanaan}

Tahap awal siklus II ini dimulai dengan menyiapkan Rencana Pelaksanaan Pembelajaran (RPP) sesuai dengan Kompetensi Inti pada Kurikulum 2013, menyiapkan soalevaluasi, lembar observasi guru, dan lembar observasi siswa.

\section{Pelaksanaan Tindakan}

Dalam tahap pelaksanaan tindakan dilaksanakan kegiatan pembelajaran sesuai dengan rencana pelaksanaan pembelajaran yang telah dibuat. Untuk dapat menyesuaikan rencana pelaksanaan pembelajaran dalam penyampaian materi, termasuk didalamnya pembelajaran dengan menggunakan kemampuan berhitung penjumlahan dan pengurangan pada tema 7 sub tema 3 kurikulum 2013 menggunakan strategi problem based learning dilaksanakan dalam 3 kali pertemuan, dimana 2 kali pertemuan untuk penyampaian materi pada pekan ketiga dan 1 kali pertemuan untuk evaluasi yaitu pekan keempat bulan Februari 2021. 


\section{Observasi dan Evaluasi}

Hasil observasi diperoleh dari hasil pengamatan yang dilakukan oleh observer yang dilakukan oleh rekan guru peneliti dengan mengisi lembar observasi aktivitas guru dan aktivitas siswa untuk merekam jalannya proses pembelajaran. Pada saat pembelajaran siklus II telah dilakukan perbaikan, dari analisis hasil observasi aktivitas siswa pada siklus II didapat bahwa aktivitas siswa tergolong aktif dalam setiap pertemuan. Hal ini dapat dilihat pada tabel skor aktivitas siswa mengalami peningkatan dari pertemuan pertama ke pertemuan ke dua, seperti yang terlihat pada tabel dibawah ini.

Tabel 4. Hasil Observasi Aktivitas Siswa Pada Siklus II

\begin{tabular}{lcccccccccc}
\hline & \multicolumn{1}{c}{ Jumlah skor yang tampak } & $\begin{array}{c}\sum \\
\text { Skor }\end{array}$ & $\begin{array}{c}\text { Rata-rata } \\
\text { Aktivitas }\end{array}$ & Kategori \\
& 1 & 2 & 3 & 4 & 5 & 6 & aktivitas & & Aktif \\
Pertama & 3,7 & 3,3 & 3,3 & 3,7 & 4,0 & 4,0 & 22 & 3,7 & Aktif \\
Kedua & 4,3 & 4,0 & 4,3 & 4,3 & 4,3 & 4,0 & 25 & 4,2 & \\
\hline
\end{tabular}

Dari tabel di atas dilihat bahwa aktivitas siswa pada siklus II untuk pertemuan 1 adalah 3.7 dan pertemuan 2 adalah 4.2. Berdasarkan penggolongan aktivitas belajar siswa maka kategori aktivitas siswa pada siklus II adalah tergolong aktif. Berdasarkan hasil evaluasi pada siklus II setelah dianalisis diperoleh data sebagai berikut:

Tabel 5. Distribusi Nilai Hasil Ulangan Siklus II

\begin{tabular}{|c|c|c|c|c|}
\hline \multirow{2}{*}{ No } & \multirow{2}{*}{ NAMA SISWA } & \multirow{2}{*}{ Nilai } & \multicolumn{2}{|c|}{ Keterangan } \\
\hline & & & Tuntas & Tidak Tuntas \\
\hline 1 & AHF & 80 & $\sqrt{ }$ & \\
\hline 2 & $\mathrm{AM}$ & 90 & $\sqrt{ }$ & \\
\hline 3 & ANB & 75 & $\sqrt{ }$ & \\
\hline 4 & AYR & 80 & $\sqrt{ }$ & \\
\hline 5 & $\mathrm{AR}$ & 80 & $\sqrt{ }$ & \\
\hline 6 & $\mathrm{DA}$ & 75 & $\sqrt{ }$ & \\
\hline 7 & DYP & 75 & $\sqrt{ }$ & \\
\hline 8 & GPM & 70 & $\sqrt{ }$ & \\
\hline 9 & II & 70 & $\sqrt{ }$ & \\
\hline 10 & KA & 70 & $\sqrt{ }$ & \\
\hline 11 & LFM & 70 & $\sqrt{ }$ & \\
\hline \multicolumn{2}{|c|}{ Jumlah } & 835 & & \\
\hline \multicolumn{2}{|c|}{ Nilai rata-rata } & 76 & & \\
\hline \multicolumn{2}{|c|}{ Nilai tertinggi } & 90 & & \\
\hline \multicolumn{2}{|c|}{ Nilai terendah } & 70 & & \\
\hline \multicolumn{2}{|c|}{ Jumlah Siswa Yang Tuntas } & \multicolumn{3}{|c|}{11 Siswa } \\
\hline \multicolumn{2}{|c|}{ Persentase Ketuntasan secara Klasikal } & \multicolumn{3}{|c|}{$100 \%$ (Tuntas) } \\
\hline
\end{tabular}

Hasil evaluasi yang diperoleh pada siklus II ini mencapai tingkat $100 \%$ jadi sudah dapat dikatakan tuntas, untuk itu tidak perlu lagi diadakan pembelajaran pada siklus berikutnya dengan ketuntasan belajar yang sudah dicapai, dengan demikian pembelajaran dengan menggunakan strategi problem based learning.

\section{Refleksi}

Dari hasil observasi aktivitas siswa pada siklus II, kegiatan pembelajaran sudah dapat berjalan dengan baik, dimana hasil observasi aktivitas siswa dapat tergolong aktif dilihat dari setiap kegiatan pembelajaran begitu juga aktivitas guru sudah tergolong sangat baik. Dari hasil analisis terhadap hasil evaluasinya terjadi peningkatan rata-rata kelas maupun persentase ketuntasan secara klasikal sudah mencapai/melebihi $85 \%$ artinya sudah $85 \%$ atau lebih siswa 
sudah mencapai nilai hasil ulangan sebesar KKM atau melebihi KKM yang ditentukan. Oleh karena itu penelitian ini dihentikan sampai siklus II sesuai dengan perencanaan.

Penelitian tindakan kelas ini dilaksanakan sebagai upaya untuk meningkatkan kemampuan berhitung penjumlahan dan pengurangan pada tema 7 sub tema 3 kurikulum 2013 menggunakan strategi problem based learningpada siswa kelas I Semester II di SDN 3 Sakra Selatan Tahun Pembelajaran 2020/2021.

Berdasarkan hasil analisis data pada tiap siklus, terlihat bahwa hasil dari siklus I ke siklus II mengalami peningkatan. Pada pelaksanaan pembelajaran dan hasil analisis data siklus I, untuk aktivitas siswa diperoleh nilai rata-rata sebesar 3.4 dan aktivitas siswa pada siklus II diperoleh nilai rata-rata kelas sebesar 4.2, Pada pelaksanaan pembelajaran dan hasil analisis data siklus I, untuk aktivitas guru diperoleh nilai rata-rata sebesar 3,4 dan aktivitas guru pada siklus II diperoleh nilai rata-rata sebesar 4,0.

Hasil evaluasi dari siklus I dan II dimana nilai yang mereka peroleh sudah mencapai tingkat ketuntasan belajar. Dan melebihi tingkat ketuntasan belajar secara klasikal yaitu 85\%. Penelitian tindakan kelas ini dilaksanaan sebagai upaya untuk meningkatkan kemampuan berhitung penjumlahan dan pengurangan menggunakan strategi problem based learningpada tema 7 sub tema 3 kurikulum 2013.

\section{KESIMPULAN}

Berdasarkan hasil penelitian dan pembahasan di atas, dapat disimpulkan bahwa meningkatkan kemampuan berhitung penjumlahan dan pengurangan menggunakan strategi problem based learning pada tema 7 sub tema 3 kurikulum 2013 di SDN 3 Sakra Selatan menjadi meningkat. Peningkatan tersebut dapat dilihat dari perolehan nilai skor aktivitas siswa, aktivitas guru dan nilai rata-rata kelas serta tingkat ketuntasan secara klasikal pada tiap siklus mengalami peningkatan baik pada siklus I maupun siklus II. Dari hasil penelitian dan pembahasan di atas dapatlah kami simpulkan: (1) Meningkatnya kemampuan berhitung penjumlahan dan pengurangan pada tema 7 sub tema 3 kurikulum 2013 menggunakan strategi problem based learning. (2) Penggunaan strategi problem based learning dapat meningkatkan kemampuan berhitung penjumlahan dan pengurangan I semester II SDN 3 Sakra Selatan tahun pelajaran 2020/2021 yang dapat dilihat dari peningkatan aktivitas belajar dari siklus I sampai dengan siklus II, dari kategori cukup aktif dengan nilai rata-rata 3.0 sampai dengan kategori aktif dengan nilai rata-rata 4.0. (3) Kemampuan berhitung penjumlahan dan pengurangan menggunakan strategi problem based learning kelas I semester II di SDN 3 Sakra Selatan Tahun Pembelajaran 2020/2021 mengalami peningkatan pada setiap siklus dengan persentase ketuntasan secara klasikal masing-masing siklus yaitu siklus I sebesar 69\% dan siklus II sebesar $100 \%$.

\section{DAFTAR PUSTAKA}

Andri, A., Zagir, Z., \& Dores, O. J. (2017). Analisis faktor-faktor yang mempengaruhi rendahnya prestasi belajar siswa pada mata pelajaran matematika di SD Negeri 04 Bati Tahun Pelajaran 2016/2017. Jurnal Pendidikan Dasar Perkhasa, 3(2), 414-426.

Anugraheni, I. (2018). Meta Analisis Model Pembelajaran Problem Based Learning dalam Meningkatkan Keterampilan Berpikir Kritis di Sekolah Dasar [A Meta-analysis of Problem-Based Learning Models in Increasing Critical Thinking Skills in Elementary Schools]. Polyglot: Jurnal Ilmiah, 14(1), 9-18.

Awe, E. Y., \& Benge, K. (2017). Hubungan antara minat dan motivasi belajar dengan hasil belajar ipa pada siswa SD. Journal of Education Technology, 1(4), 231-238.

Fitriani, K., \& Maulana, M. (2016). Meningkatkan Kemampuan Pemahaman dan Pemecahan Masalah Matematis Siswa SD Kelas V Melalui Pendekatan Matematika Realistik. Mimbar Sekolah Dasar, 3(1), 40-52. 
Gunantara, G., Suarjana, I. M., \& Riastini, P. N. (2014). Penerapan model pembelajaran problem based learning untuk meningkatkan kemampuan pemecahan masalah matematika siswa kelas V. Mimbar PGSD Undiksha, 2(1).

Indriani, A. (2016). Pengaruh motivasi belajar siswa kelas V terhadap prestasi belajar matematika di SD Negeri Bejirejo Kecamatan Kunduran Kabupaten Blora. JIPM (Jurnal Ilmiah Pendidikan Matematika), 4(2), 134-139.

JAYANTIKA, I. G. A. N. T., Ardana, I. M., \& Sudiarta, P. I. G. P. (2013). Kontribusi bakat numerik, kecerdasan spasial, dan kecerdasan logis matematis terhadap prestasi belajar matematika siswa SD Negeri di Kabupaten Buleleng. Jurnal Pendidikan dan Pembelajaran Matematika Indonesia, 2(2).

Muakhirin, B. (2014). Peningkatan hasil belajar IPA melalui pendekatan pembelajaran inkuiri pada siswa SD. Jurnal ilmiah guru caraka olah pikir edukatif, (1).

Savery, J. R. (2015). Overview of problem-based learning: Definitions and distinctions. Essential readings in problem-based learning: Exploring and extending the legacy of Howard S. Barrows, 9(2), 5-15.

Sulfemi, W. B., \& Minati, H. (2018). Meningkatkan Hasil Belajar Peserta Didik Kelas 3 SD Menggunakan Model Picture And Picture dan Media Gambar Seri. JPsd (Jurnal Pendidikan Sekolah Dasar), 4(2), 228-242

Warti, E. (2016). Pengaruh motivasi belajar siswa terhadap hasil belajar matematika siswa di SD Angkasa 10 Halim Perdana Kusuma Jakarta Timur. Mosharafa: Jurnal Pendidikan Matematika, 5(2), 177-185. 